\title{
関節モーメントによる健常者の段昇降分析
}

$\begin{array}{lll}\text { 黒後 裕彦*1 } & \text { 飛松 好子*2 } & \text { 毛利 光宏*2 } \\ \text { 大町かおり*2 } & \text { 岩谷 } \text { 力 }^{* 2} & \text { 鈴木 堅二*3 }\end{array}$

\section{Analysis of Joint Moment in Healthy Adults Ascending and Descending Steps}

\author{
Hirohiko Kurogo, ${ }^{* 1}$ Yoshiko Tobimatsu, ${ }^{* 2}$ Mitsuhiro Mouri, ${ }^{* 2}$ \\ Kaori Ohmachi, ${ }^{* 2}$ Tsutomu Iwaya, ${ }^{* 2}$ Kenji Suzuki ${ }^{* 3}$
}

\begin{abstract}
The purpose of this study was to investigate the influence of height of risers on the force generated by a person ascending and descending steps. Force plates and a 3dimensional motion analyzer were used to evaluate the stepping motion of 12 healthy adults ascending and descending steps, and the moments in the hip, knee, and ankle joint areas were calculated. In ascending, the extension moments of the hip and knee joints of the lead leg generated accelerating force. In descending, decelerating force was generated by the extension moments of the hip and knee joints, by the planter flexion moments of the ankle joint of the lead leg, and by the extension moment of the knee joint of the trail leg. The results of the present study indicated that height of stair risers influenced the magnitude of the force generated by a person ascending and descending steps but did not influence the pattern of the force that was generated. (Jpn J Rehabil Med 2000; 37: 389-397)
\end{abstract}

要 旨：健常者 12 例を対象に段昇降動作を床反力計と 3 次元動作解析装置で測定した。段 昇降時の股関節，膝関節，足関節の関節モーメントを求め，段高の違いが各関節の生体が発す る力に与える影響を検討した。昇段では, 先に振り出した脚の股関節と膝関節の伸展モーメン トが駆動力として働き，降段では先に振り出した脚の股関節と膝関節の伸展モーメントと足関 節底屈モーメントならびに, 後から振り出す脚の膝関節伸展モーメントが制動力として働いて いた，段昇降動作時において段の高さの違いは生体が発する力の大きさに影響を与えたが，生 体が発する力のパターンには影響を与えなかった（リハ医学 $2000 ； 37: 389-397$ )

Key words : 健常人 (healthy adult), 関節モーメント（joint moment）, 段昇降（step ascending and descending)

\section{研究背景}

日常生活では階段や段を昇降する機会は多く，これ らの動作での運動学的および運動力学的解析 ${ }^{1-3)}$ が報 告されてきた。それらの多くは，階段や段の高さをひ とつに設定して解析を行っている. しかし, 日常にお ける階段や段の高さは必ずしも一定ではない.
いくつかの段の高さで行われた段昇降動作を運動学 的ならびに運動力学的に比較検討した報告がある. 運 動学的な解析では, 健常者は段の高さの違いにより下 肢関節や骨盤回旋の角度を変えて対応していると報告 されている4). 運動力学的な解析では, 健常者と下腿 切断者を対象に床反力計を用いた分析があり, 両群の 降段時の最大垂直分力は段が高いほど増大すると述べ

2000 年 2 月 2 日受付, 2000 年 5 月 8 日受理

*1 東北文化学園大学医療福祉学部リハビリテーション学科/テ 981-8551 宮城県仙台市青葉区国見 6-45-16

Department of Rehabilitation, Faculty of Medical Science \& Welfare, Tohoku Bunka Gakuen University

*2 東北大学大学院医学系研究科障害科学専攻運動障害学講座肢体不自由学分野/ $980-0872$ 宮城県仙台市青葉区星陵町 2-1

Rehabilitation Medicine for the Physically Disabled, Tohoku University Graduate School of Medicine

*3 帝京大学医学部附属市原病院リハビリテーション科/テ 299-0111 千葉県市原市姉崎 3426-3

Department of Rehabilitation Medicine, Ichihara Hospital, Teikyo University School of Medicine 
られている5).しかし，これまで異なる段の高さでの 段昇降動作を関節モーメントによって検討した報告は ない.

身体の各部位を剛体リンクモデルに置き換えると， 各関節の運動は回転運動としてとらえることができ る. 静止した状態の関節に回転運動を生じさせるに は, 力のモーメントが必要である6).この力のモーメ ントを計測するには，通常，等尺性および等運動性に 筋肉を収縮させ，そのときの外力により計測する方法 がとられる。したがって，力のモーメントの測定は筋 力測定と同じ意味となる. しかし，この方法では段昇 降のような動作中の力のモーメントを求めることはで きない.

床反力計と 3 次元動作解析装置を使うと動作中の力 のモーメントを求めることができる77.この場合の力 のモーメントには重力と慣性力と床からの反力などの 影響が含まれているので，それらを除く必要がある。 そうして求められたモーメントを関節モーメントとす る $^{8)}$ と関節モーメントとは生体が発する力と関係する といえる。この生体が発する力とは筋力のことであ り，それゆ元関節モーメントは動作中の筋力を推定す るための一手段といえる ${ }^{8,9)}$. しかし，関節モーメン トが表す筋力とは主動筋や拮抗筋など関節に作用する すべての筋からなる合力としての筋力である ${ }^{10)}$.

段昇降動作において関節モーメントを測定すると， 各関節での生体が発する力の程度とその経時的変化の 把握が可能となる，そのため，生体が発する力が段の 高さの異なる昇降動作によってどのような影響を受け るのかを検討することができる。

今回の研究の目的は，健常者を対象にして，2 足 1 段型での段昇降時の股関節，膝関節，足関節の各関節 での生体が発する力が段の高さの違いによってどのよ うな影響を受けるかを検討することである.

\section{研 究方法}

\section{1. 対 象}

健常女性 12 例を対象とした。平均年齢は $19.7 \pm$ 2.6 歳 (18〜28 歳), 平均身長は $157.5 \pm 1.9 \mathrm{~cm}$ $(154.1 \sim 161.0 \mathrm{~cm})$, 平均体重は $50.5 \pm 4.9 \mathrm{~kg}(42.0$ 〜 $57.4 \mathrm{~kg}$ ）であった。 全例, 定期的なスポーツ習慣 はなく, 整形外科的疾患ならびに神経疾患の既往はな かった.

\section{2. 方 法 \\ 1) 運動課題}

被験者は安静立位から，先に振り出す脚を右脚（以 下, 先脚) とし, 後から振り出す脚を左脚 (以下, 後 脚）とした昇段と降段の 2 足 1 段動作を行った。昇降 する段の高さを $10 \mathrm{~cm}, 20 \mathrm{~cm}, 30 \mathrm{~cm}$ の 3 種類とし た（図 1)。

\section{2）昇降方法と手順}

被験者は床反力計上で両腕を胸の前で組み，裸足で 直立安静立位をとった．動作開始時の足部の位置は股 関節の内外旋を任意として，両足内側部を正中線から 左右にそれぞれ $5 \mathrm{~cm}$ とした。また両足先端と台の端 との距離は $7 \mathrm{~cm}$ とした。

被験者は測定開始前に昇降練習を数回行った後，検 者の合図で動作を開始した。昇降速度に関しては，日 常的に自然に行っている速度とした（表 1)。測定順 序はランダムとし，測定回数は各段の昇降につき 3 回 とした。

\section{3）測定項目}

身体の 3 次元変位は被験者に直径 $2.5 \mathrm{~cm}$ の球形反 射マーカーを貼付し，それを計測の標点として求め

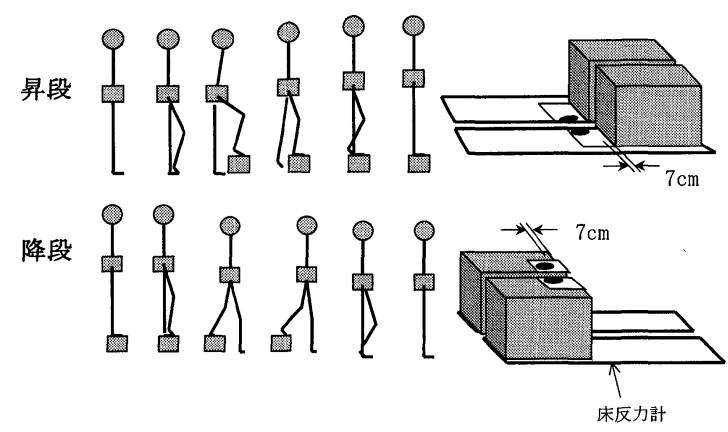

図 1 昇降動作と台の設定位置 昇段，降段とも右脚から振り出す 2 足 1 段動作とした。昇 降用の 2 個の台を床反力計上の図に示した位置に設定し た.

表 1 全所要時間 $(n=12)$

\begin{tabular}{|c|c|c|c|}
\hline & 高さ & 全所要時間 (秒) & \\
\hline \multirow[t]{3}{*}{ 昇段時 } & $10 \mathrm{~cm}$ & $2.48 \pm 0.20$ & \\
\hline & $20 \mathrm{~cm}$ & $2.55 \pm 0.19$ & \\
\hline & $30 \mathrm{~cm}$ & $2.61 \pm 0.17$ & \\
\hline \multirow[t]{3}{*}{ 降段時 } & $10 \mathrm{~cm}$ & $2.33 \pm 0.12=$ & \\
\hline & $20 \mathrm{~cm}$ & $2.53 \pm 0.17 \sqcup^{* *}$ & F \\
\hline & $30 \mathrm{~cm}$ & $2.52 \pm 0.15$ & \\
\hline
\end{tabular}


た. 貼付部位は両側の肩峰，股関節（大転子と上前腸 骨棘とを結ぶ線上で大転子から $1 / 3$ の位置)，膝関節 (大腿骨内転筋結節と膝関節裂隙の中央の高さで, 膝 蓋骨を除いた膝の前後径の中点の位置で, 膝の外側皮 膚面), 外果, 第五中足骨頭であった ${ }^{8)}$.

床反力の測定では, 床反力計を使って垂直, 前後, 左右方向の 3 分力を求めた. 3 次元動作解析装置と床 反力計を同期させ，両者のデータをサンプリング周波 数 $60 \mathrm{~Hz}$ で取り込み, 各標点座標ならびに床反力の 時間的変化を記録した。

\section{4) 計測機器}

床反力と画像データの測定には $600 \times 900 \mathrm{~mm}$ の水 晶圧電式多成分床反力計（キスラー社製，9287 A） 2 基とチャージアンプ（キスラー社製，9865 c） 2 基, 測定電荷結合型素子カメラ 7 基, 3 次元動作解析シス
テム（オックスフォードメトリクス社製, Vicon 370) を用いた。

3 種類の段高を設定するために $10 \mathrm{~cm}, 20 \mathrm{~cm}, 30$ $\mathrm{cm}$ の高さの木製の台を 2 個ずつ作製した. 2 基の床 反力計が床と同じ高さで平行に埋め込まれており，そ の上に高さの同じ 2 個の台を設置した（図 1).

\section{3. 分析対象と产の算出方法}

1）関節角度変化曲線

3 次元動作解析システムより得られた各標点座標と 床反力データの高周波ノイズをバタワース特性のデジ タルフィルターを用いて除去した．各標点座標データ に対する遮断周波数を $6 \mathrm{~Hz}$ ，床反力データに対する 遮断周波数を $20 \mathrm{~Hz}$ として処理した。

各標点座標データをもとに両側の股関節屈伸, 膝関 節屈伸, 足関節底背屈の各関節角度を求め, 全所要時
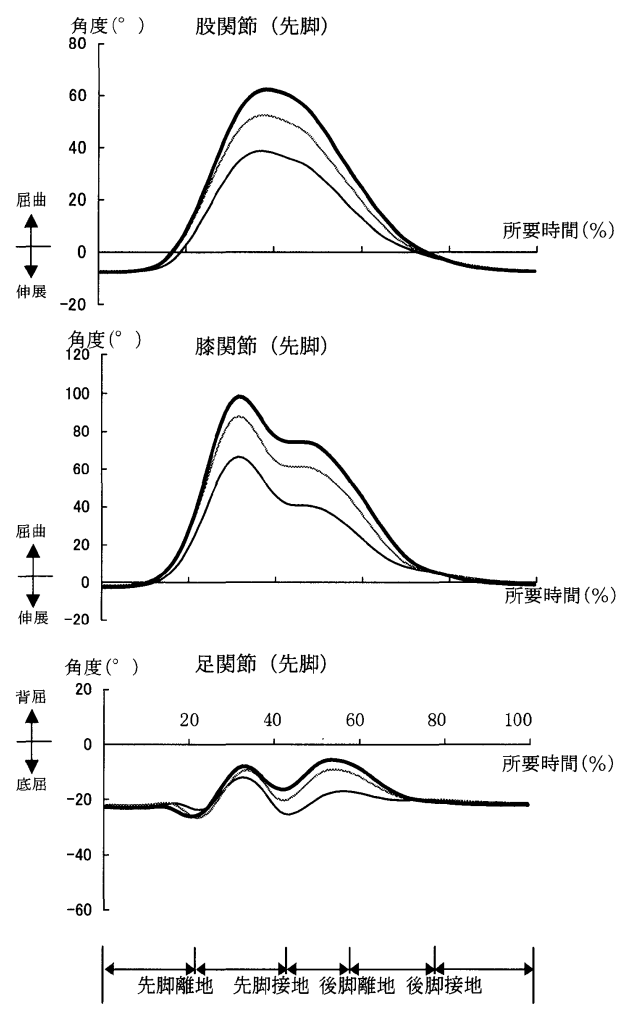

先に振り出す脚 (先脚)
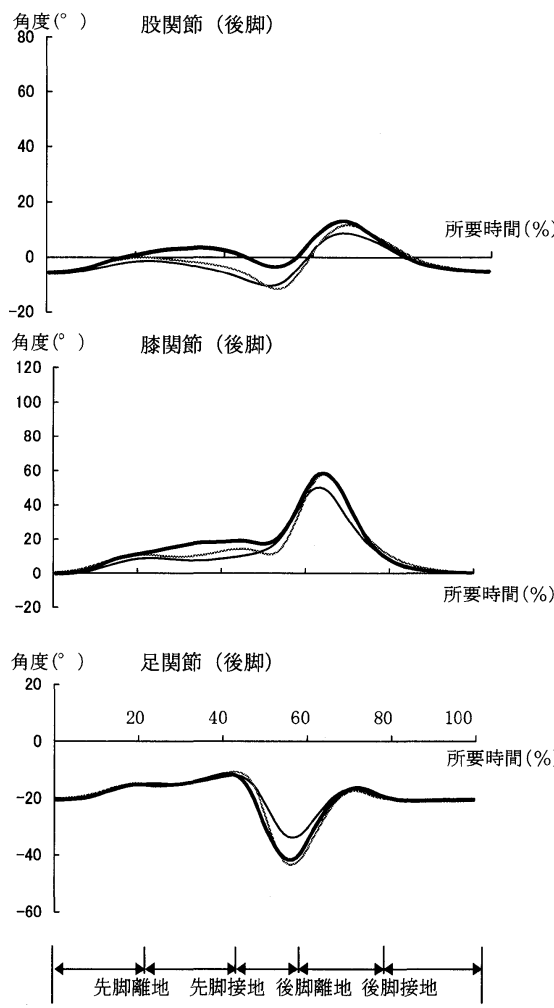

後から振り出す脚（後脚）

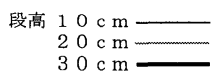

図 2 昇段時の下肢の関節角度变化曲線 $(n=12)$

各グラフとも縦軸は関節角度，横軸は所要時間. 所要時間は昇段開始時から終了時までを $100 \%$ と して表示している. 
間を $100 \%$ とて正規化し，各関節の角度変化曲線を 求めた.

2) 関節モーメント曲線と関節モーメントの最大值

\section{と铚の出現時期}

各標点座標と床反力のデータをもとに JMOME $5 \mathrm{~A}$ (臨床歩行分析研究会) ${ }^{8)}$ を使用して両側の股関節屈 伸，膝関節屈伸，足関節底背屈の各関節モーメントを 求め，その值を体重で除した。全所要時間を $100 \%$ と して正規化し, 各関節のモーメント曲線と関節モーメ ントの最大值を求めた。 また動作開始時から関節モー メントの最大值を示した時までの時間の全所要時間に 対する百分率を最大出現時間 (\%) とし，その值を求め た。 各関節モーメントの最大值とその出現時間の值 を, 各動作ごとに個人ごと $(n=3)$ の平均処理し, 12 例の值の平均值を求めた。

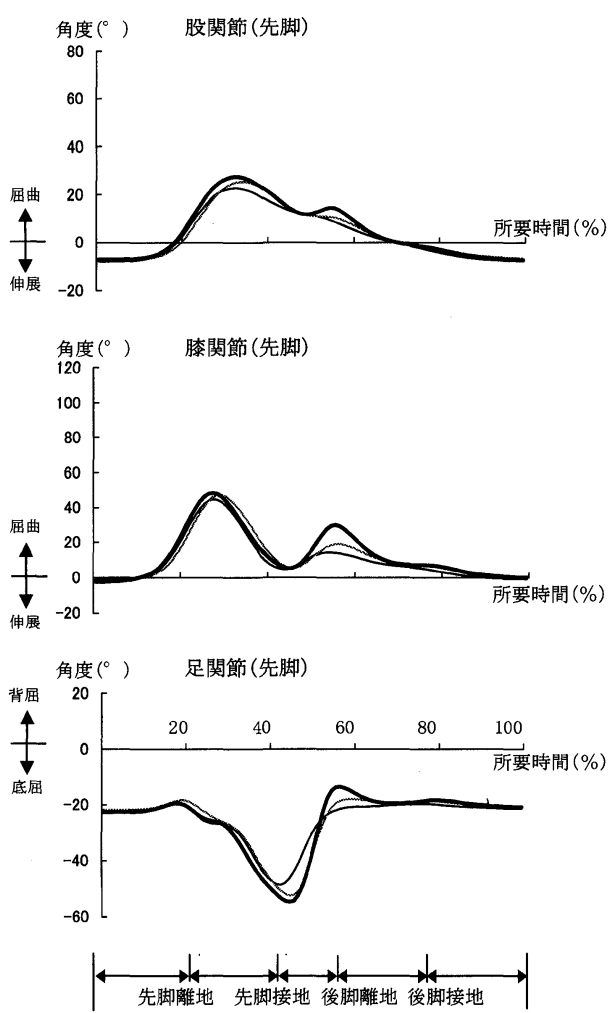

先に振り出す脚（先脚）
動作の開始や終了ならびに各相を区分する時点を床 反力データから以下のように求めた．動作の開始は垂 直分力が変動し始める時点, 先脚離床時は右床反力計 の垂直成分が消失する時点，先脚接地時は右床反力計 の垂直成分が再び出現する時点, 後脚離床時は左床反 力計の垂直成分が消失する時点, 後脚接地時は左床反 力計の垂直成分が再び出現する時点, 動作の終了は垂 直分力の変動が静止する時点とした ${ }^{5)}$.

\section{4. 統計学的検討}

段高の違いによる関節モーメントの最大值とその出 現時間については 1 元配置分散分析を行い，事後検定 には Scheffe の方法を用いた。危険率 5\%未満をもつ て統計的に有意とした。
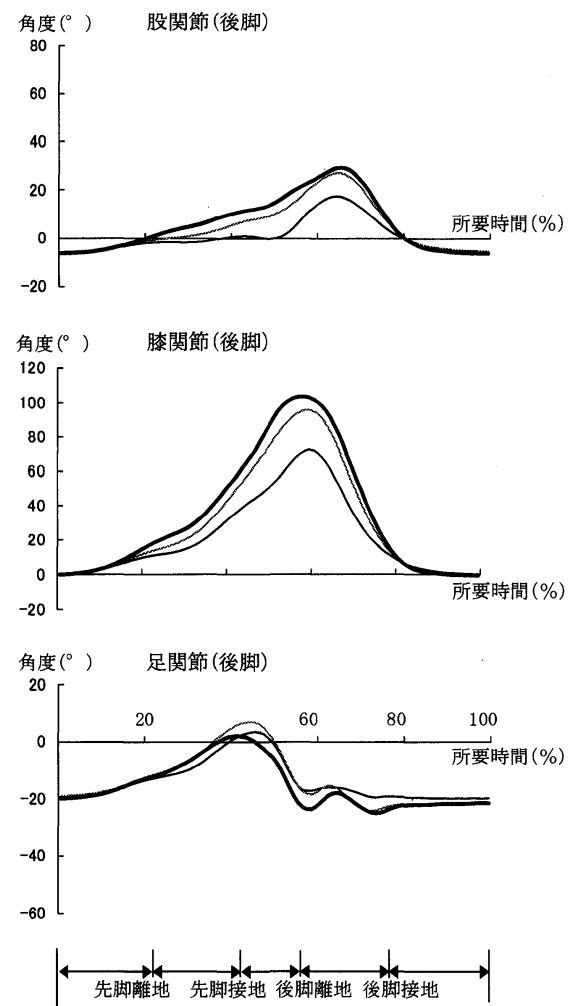

後から振り出す脚（後脚）

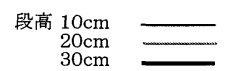

図 3 降段時の下肢の関節角度変化曲線 $(n=12)$

各グラフとも縦軸は関節角度，横軸は所要時間。所要時間は降段開始時から終了時までを $100 \%$ と して表示している. 
表 2 昇段時の関節モーメントの最大値とその出現時期 $(n=12)$

\begin{tabular}{|c|c|c|c|c|c|}
\hline \multirow{2}{*}{ 高さ } & \multicolumn{3}{|c|}{ 先に振り出す脚（先脚） } & \multicolumn{2}{|c|}{ 後から振り出す脚（後脚） } \\
\hline & \multicolumn{2}{|c|}{ 最大値（Nm/kg） } & 出現時期 (\%) & 最大値（Nm/kg） & 出現時期（\%） \\
\hline \multicolumn{6}{|c|}{ 股関節屈曲モーメント } \\
\hline $10 \mathrm{~cm}$ & \multicolumn{2}{|l|}{$0.20 \pm 0.03 \square$} & $28.8 \pm 4.9$ & $0.05 \pm 0.05$ & $50.9 \pm 6.2$ \\
\hline $20 \mathrm{~cm}$ & $0.22 \pm 0.03 \quad * *$ & & $28.2 \pm 2.5$ & \multirow{2}{*}{$\begin{array}{l}0.13 \pm 0.10 \\
0.15 \pm 0.09\end{array}$} & $51.7 \pm 2.6$ \\
\hline $30 \mathrm{~cm}$ & \multicolumn{2}{|l|}{$0.25 \pm 0.04-$} & $28.1 \pm 3.3$ & & $50.8 \pm 3.1$ \\
\hline \multicolumn{6}{|c|}{ 股関節伸展モーメント } \\
\hline $10 \mathrm{~cm}$ & $0.30 \pm 0.09 \overline{7 * *}$ & \multirow{3}{*}{ ** } & $50.7 \pm 6.1$ & $0.22 \pm 0.09 \sqsupset$ & $41.8 \pm 7.0$ \\
\hline $20 \mathrm{~cm}$ & $0.53 \pm 0.15 二_{* *}^{* *}$ & & $50.5 \pm 4.5$ & $0.25 \pm 0.10$ & $40.8 \pm 4.2$ \\
\hline $30 \mathrm{~cm}$ & $0.79 \pm 0.15 \beth^{* *}$ & & $51.7 \pm 3.4$ & $0.32 \pm 0.13-$ & $40.7 \pm 5.1$ \\
\hline \multicolumn{6}{|c|}{ 膝関節伸展モーメント } \\
\hline $10 \mathrm{~cm}$ & $0.70 \pm 0.13 \overline{\overline{7}}$ & \multirow{3}{*}{ ** } & $53.8 \pm 6.0$ & $0.16 \pm 0.09$ & $21.3 \pm 3.9$ \\
\hline $20 \mathrm{~cm}$ & $1.05 \pm 0.19\rfloor^{* *}$ & & $53.6 \pm 4.8$ & $0.20 \pm 0.15$ & $19.9 \pm 2.0$ \\
\hline $30 \mathrm{~cm}$ & $1.19 \pm 0.23$ & & $55.6 \pm 3.2$ & $0.24 \pm 0.13$ & $20.6 \pm 2.6$ \\
\hline \multicolumn{6}{|c|}{ 膝関節屈曲モーメント } \\
\hline $10 \mathrm{~cm}$ & & & & $0.37 \pm 0.14$ & $44.8 \pm 5.1$ \\
\hline $20 \mathrm{~cm}$ & & & & $0.35 \pm 0.26$ & $45.6 \pm 7.5$ \\
\hline $30 \mathrm{~cm}$ & & & & $0.27 \pm 0.21$ & $44.2 \pm 6.5$ \\
\hline \multicolumn{6}{|c|}{ 足関節底屈モーメント } \\
\hline $10 \mathrm{~cm}$ & $0.49 \pm 0.18$ & & $72.2 \pm 8.4$ & $1.20 \pm 0.16$ & $46.2 \pm 5.8$ \\
\hline $20 \mathrm{~cm}$ & $0.45 \pm 0.12$ & & $67.0 \pm 8.3$ & $1.30 \pm 0.14$ & $47.5 \pm 2.4$ \\
\hline $30 \mathrm{~cm}$ & $0.46 \pm 0.12$ & & $70.9 \pm 6.9$ & $1.42 \pm 0.14$ & $47.3 \pm 3.0$ \\
\hline
\end{tabular}

平均值士標準偏差, ${ }^{*} p<0.05,{ }^{* *} p<0.01$

\section{結果}

\section{1. 段昇降時の全所要時間}

段昇降動作開始時から終了時までの所要時間を表 1 に示す。

\section{2. 関節角度变化曲線}

昇段では，どの高さの段においても先脚が上段に接 地した後, 先脚の股関節と膝関節の角度は伸展し続け ていた（図 2).降段での後脚の膝関節角度変化曲線 は段高 $20 \mathrm{~cm}$ 時と段高 $30 \mathrm{~cm}$ 時ではほほ同様のパ夕 ーンを示していた（図 3).

3. 関節モーメント曲線および関節モーメントの最 大值とその出現時期

1）昇段時の関節モーメントの最大值と炎の出現時 期への段高の影響

昇段時の先脚股伸展モーメントの最大值は段高 10 $\mathrm{cm}$ 時より段高 $20 \mathrm{~cm}$ 時ならびに段高 $30 \mathrm{~cm}$ 時で有意 に大きく, 段高 $20 \mathrm{~cm}$ 時より段高 $30 \mathrm{~cm}$ 時で有意に 大きかった（表 2). 先脚膝伸展モーメントの最大值 は段高 $10 \mathrm{~cm}$ 時より段高 $20 \mathrm{~cm}$ 時ならびに段高 30 $\mathrm{cm}$ 時で有意に大きかった. 先脚股伸展と先脚膝伸展 モーメントの最大值の出現時期は両方とも先脚が上段 で接地し, 後脚が下段で接地している両脚支持期に示
された（図4). 各関節モーメント曲線のパターンは 同様であり，関節モーメントの最大値の出現時間は段 高の変化による影響を受けなかった。

2) 降段時の関節モーメントの最大值と炎の出現時 期への段高の影響

降段時の先脚股伸展モーメントの最大值は段高 10 $\mathrm{cm}$ 時より段高 $30 \mathrm{~cm}$ 時で有意に大きかった（表 3). 先脚膝伸展モーメントの最大值は段高 $10 \mathrm{~cm}$ 時より 段高 $30 \mathrm{~cm}$ 時で有意に大きく, 段高 $20 \mathrm{~cm}$ 時より段 高 $30 \mathrm{~cm}$ 時で有意に大きかった. 先脚足関節底屈モ ーメントの最大值は段高 $10 \mathrm{~cm}$ 時より段高 $20 \mathrm{~cm}$ 時 ならびに段高 $30 \mathrm{~cm}$ 時で有意に大きく, 段高 $20 \mathrm{~cm}$ 時より段高 $30 \mathrm{~cm}$ 時で有意に大きかった. 先脚の股 伸展と膝伸展と足関節底屈での関節モーメントにおけ る最大值の出現時期は後脚が上段で接地し, 先脚が下 段で接地している両脚支持期に示された（図 5).

後脚膝伸展モーメントの最大值は段高 $10 \mathrm{~cm}$ 時よ り段高 $20 \mathrm{~cm}$ 時ならびに段高 $30 \mathrm{~cm}$ 時で有意に大き かった (表 3). 後脚膝伸展モーメントの最大值の出 現時期は後脚で上段を接地し, 先脚が離地している時 期に示された（図 5).

足関節底屈以外の各関節モーメントの最大值の出現 時間は段高の変化による影響を受けなかった。 

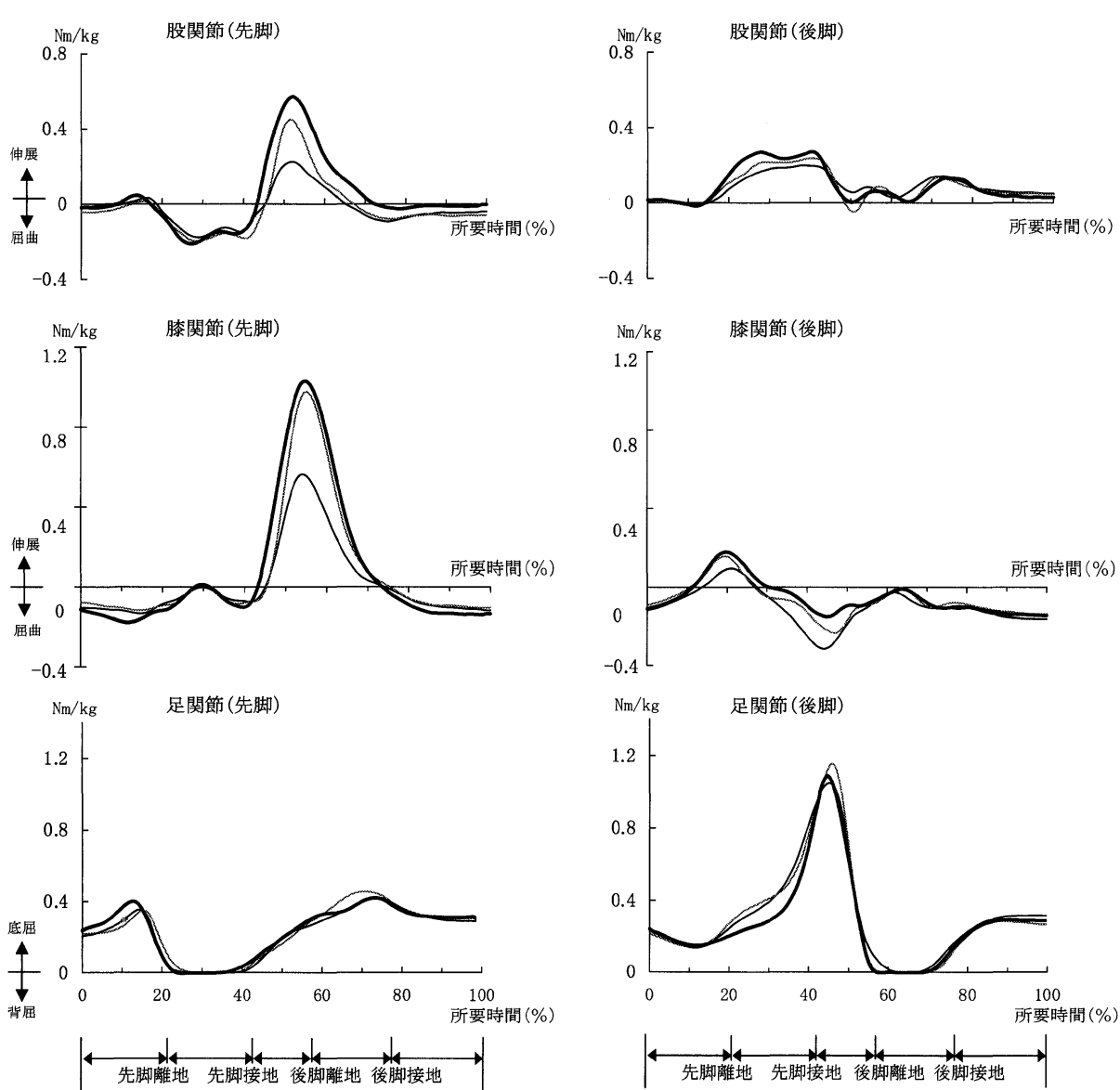

後から振り出す脚（後脚）

先に振り出す脚（先脚）

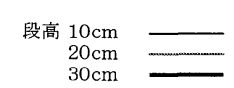

図 4 昇段時の下肢の関節モーメント曲線 $(n=12)$

各グラフとも縦軸はモーメントを体重で除した値, 横軸は所要時間. 所要時間は昇段開始時から終 了時まで $100 \%$ として表示している.

\section{考 察}

段昇降動作を分析するにあたって，身長と体重の影 響を考慮し1)，ほほ同様な身長の被験者を対象とし た. 体重の標準偏差が大きいので，モーメントの值を 体重で除して比較検討した。.また，被験者は段昇降を 自然な速度で行ったが，所要時間に大きなばらつきは 認められなかった。

昇段時において，先脚の股伸展と膝伸展モーメント の最大值は段が高くなるにつれて有意に大きくなった が, 唯一, 膝伸展モーメントの最大值は段高 $20 \mathrm{~cm}$ 時と段高 $30 \mathrm{~cm}$ 時で有意差はなかった. 両伸展モー
メントの最大值の出現時期は先脚が上段で接地し, 後 脚が下段で接地している両脚支持期で示されていた。 これらのことから昇段時に体幹を上方へ移動するに は，股伸展力と滕伸展力が必要であり，段が高くなる と股伸展力がより必要となると考えられた。一方, 昇 段時の足関節底屈モーメントの最大值は両側とも段高 の影響がなかった。平地歩行時での足関節底屈モーメ ントの最大值は推進期で示され，植松 ${ }^{11)}$ で約 1.3 $\mathrm{Nm} / \mathrm{kg}, W^{2}$ inter $^{12)}$ で約 $1.5 \mathrm{Nm} / \mathrm{kg}$ であり, 今回と 同じような值を示している。そのため足関節底屈力は 平地歩行と同程度の力であり, それは段の高さにかか わらず体幹の前方への推進力として寄与していると考 
表 3 降段時の関節モーメントの最大值とその出現時期 $(n=12)$

\begin{tabular}{|c|c|c|c|c|c|c|c|}
\hline \multirow{2}{*}{ 高さ } & \multicolumn{3}{|c|}{ 先に振り出す脚 (先脚) } & \multicolumn{4}{|c|}{ 後から振り出す脚（後脚） } \\
\hline & \multicolumn{2}{|c|}{ 最大值 $(\mathrm{Nm} / \mathrm{kg})$} & 出現時期(\%) & \multicolumn{2}{|l|}{ 最大値 $(\mathrm{Nm} / \mathrm{kg})$} & \multicolumn{2}{|c|}{ 出現時期 (\%) } \\
\hline \multicolumn{8}{|c|}{ 股関節屈曲モーメント } \\
\hline $10 \mathrm{~cm}$ & \multicolumn{2}{|l|}{$0.17 \pm 0.03$} & $25.9 \pm 3.1$ & \multicolumn{2}{|l|}{$0.24 \pm 0.09$} & \multicolumn{2}{|l|}{$49.9 \pm 2.1$} \\
\hline $20 \mathrm{~cm}$ & \multicolumn{2}{|l|}{$0.14 \pm 0.11$} & $26.1 \pm 3.0$ & \multicolumn{2}{|l|}{$0.27 \pm 0.08$} & \multicolumn{2}{|l|}{$51.4 \pm 2.6$} \\
\hline $30 \mathrm{~cm}$ & \multicolumn{2}{|l|}{$0.19 \pm 0.06$} & $24.7 \pm 3.3$ & \multicolumn{2}{|l|}{$0.31 \pm 0.08$} & \multicolumn{2}{|l|}{$50.6 \pm 2.4$} \\
\hline \multicolumn{8}{|c|}{ 股関節伸展モーメント } \\
\hline $10 \mathrm{~cm}$ & \multicolumn{2}{|l|}{$0.26 \pm 0.11 \neg$} & $51.1 \pm 1.6$ & \multirow{2}{*}{\multicolumn{2}{|c|}{$\left.\begin{array}{l}0.18 \pm 0.02 \\
0.12 \pm 0.03\end{array}\right]^{* *}$}} & \multicolumn{2}{|l|}{$70.1 \pm 2.9$} \\
\hline $20 \mathrm{~cm}$ & $0.33 \pm 0.14$ & & $52.1 \pm 2.6$ & & $* *$ & $71.8 \pm 4.6$ & \\
\hline $30 \mathrm{~cm}$ & \multicolumn{2}{|l|}{$0.43 \pm 0.18$} & $52.6 \pm 2.5$ & \multicolumn{2}{|l|}{$0.12 \pm 0.03$} & $70.0 \pm 3.9$ & \\
\hline \multicolumn{7}{|c|}{ 滕関節伸展モーメント } & \\
\hline $10 \mathrm{~cm}$ & \multicolumn{2}{|l|}{$0.18 \pm 0.20$} & $57.9 \pm 4.6$ & \multirow{3}{*}{$\begin{array}{l}0.64 \pm 0.21 \\
0.96 \pm 0.23 \\
1.06 \pm 0.26\end{array}$} & & \multirow{3}{*}{\multicolumn{2}{|c|}{$\begin{array}{l}46.2 \pm 2.3 \\
46.4 \pm 2.0 \\
45.3 \pm 2.4\end{array}$}} \\
\hline $20 \mathrm{~cm}$ & $0.33 \pm 0.28 \square_{* *}$ & ** & $56.9 \pm 3.3$ & & ** & & \\
\hline $30 \mathrm{~cm}$ & \multicolumn{2}{|l|}{$0.69 \pm 0.28 \beth^{* *}$} & $54.3 \pm 2.1$ & & & & \\
\hline \multicolumn{8}{|c|}{ 足関節底屈モーメント } \\
\hline $10 \mathrm{~cm}$ & \multirow{3}{*}{\multicolumn{2}{|c|}{$\begin{array}{l}0.67 \pm 0.10 \overline{Z^{* *}} \\
0.99 \pm 0.21 \bar{*}^{* *} \\
1.40 \pm 0.29\end{array}$}} & $54.3 \pm 3.3$ & \multirow{3}{*}{\multicolumn{2}{|c|}{$\begin{array}{l}1.11 \pm 0.13 \\
1.10 \pm 0.11 \\
1.07 \pm 0.10\end{array}$}} & $43.4 \pm 2.5-$ & \\
\hline $20 \mathrm{~cm}$ & & & $53.6 \pm 3.6$ & & & $43.3 \pm 2.3 \sqsupset *$ & $*$ \\
\hline $30 \mathrm{~cm}$ & & & $51.7 \pm 2.1$ & & & $40.7 \pm 2.2 \beth^{*}$ & \\
\hline
\end{tabular}

平均値士標準偏差, ${ }^{*} p<0.05, * * p<0.01$

えられた。

先脚の股関節の伸展モーメントの最大值は先脚が上 段へ接地した後の立脚期に示されていた。平地歩行で も股伸展モーメントの最大値は立脚期前半で示されて いる ${ }^{12,13)}$. 平地歩行での股伸展モーメントの役割は, 立脚初期で体幹が大きく前傾しないための制動力とし て働くためと説明されている13,14). 平地歩行の立脚初 期では床反力により下肢の前方への動きが制動される が，それに伴って体重心に前方への慣性力が発生す る。このままでは体幹が前傾してしまうため, 股伸展 モーメントが必要になるとされている。これに対し昇 段時での股伸展モーメントが制動力とは考えにくい. 関節角度をみると昇段時で先脚が上段に接地した後も 先脚の股と膝関節は伸展を続けていた。これはどの高 さの段でも認められた，宮原らは今回の研究と同一の 条件で健常者の段昇降における下肢の関節角度を調べ ている4)が，その報告でも同じような結果を示してい る. 今回の研究において, 同じ時期に先脚の股伸展と 膝伸展モーメントが認められることから，股と膝関節 の伸筋群は求心性収縮をしていると考えられた。その ため, 昇段動作での股と膝関節の伸展力は, 先脚が上 段へ接地した後に体幹を上方に移動させるための駆動 力として働くと考えられた。

降段時の先脚の足関節底屈モーメントの最大值は段 が高くなると有意に大きくなった。それに対して先脚 の股伸展と膝伸展モーメントの最大值は段高 $10 \mathrm{~cm}$
時と段高 $20 \mathrm{~cm}$ 時では有意差はなかったが，段高 10 $\mathrm{cm}$ 時と段高 $30 \mathrm{~cm}$ 時ではそれぞれ有意に大きくなっ た。これらの最大値の出現時期は後脚が上段で接地 し, 先脚が下段で接地している両脚支持期で示され た。降段時では段が低い場合はおもに先脚の足関節底 屈力の増大により下肢の屈曲方向への回転モーメント を制動し, 段が高くなると, 膝伸展力や股伸展力も増 大させて対応していると考えられた。

先脚が床に接地するまでの間で後脚が単脚支持して いる相では, 後脚の膝伸展モーメントの最大値は段高 $10 \mathrm{~cm}$ 時より段高 $20 \mathrm{~cm}$ 時で有意に大きかったが，段 高 $20 \mathrm{~cm}$ 時と段高 $30 \mathrm{~cm}$ 時では有意差がなかった。 後脚の膝関節の角度変化曲線は段高 $20 \mathrm{~cm}$ 時と段高 $30 \mathrm{~cm}$ 時ではほぼ同じである. 宮原ら ${ }^{4)}$ の段昇降での 関節角度の報告でも, 降段時の後脚の膝屈曲角度の最 大值は段高 $20 \mathrm{~cm}$ 時と段高 $30 \mathrm{~cm}$ 時で有意差がなく, 膝関節の角度変化曲線はほぼ同じパターンを示してい る.これらのことから，段高 $20 \mathrm{~cm}$ 時までは後脚の 膝伸展力によって体幹の下方への移動は制動される が，それ以上の高さでは後脚の制動力は変わらず，も し先脚の離床から下段へ接地するまでの実時間が段が 高くなるほど長くなるとするならば，重心の下方への 速度は重力の影響によって増大すると考えられた。 あ る高さ以上では後脚の膝伸展力による体幹の下方への 制動力を増すことができず，それに伴う体重心の下方 への速度はより大きくなり, 先脚が下段に接地した時 

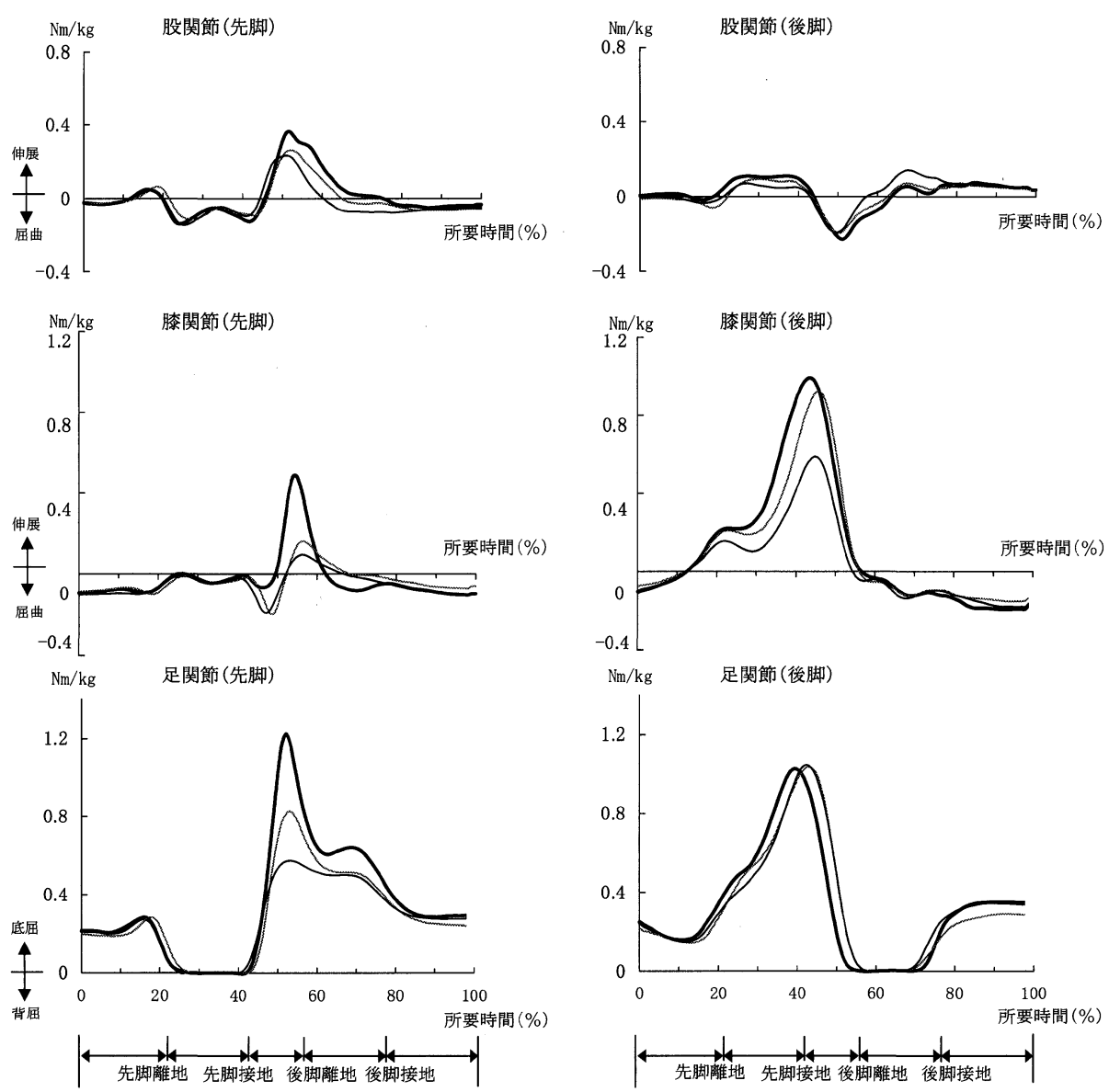

後から振り出す脚（後脚）

先に振り出す脚（先脚）

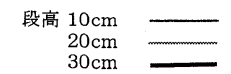

図 5 降段時の下肢の関節モーメント曲線 $(n=12)$

各グラフとも縦軸はモーメントを体重で除した值，横軸は所要時間. 所要時間は降段開始時から終 了時までを $100 \%$ とて表示している.

の先脚の股と膝の伸展力によって下肢の屈曲方向への 回転モーメントを制動すると考えられた。

今回の研究において，各関節モーメントはどの高さ の段昇降においても同様のパターンを示し, その最大 值の出現時期にも段高の違いによる影響がほとんどな かった.このことは, 段の高さが異なっていても各関 節の生体が発する力はその経時的なパターンを変え ず，力の大きさのみを変え対処していることを示して いた．そして生体が発する力の大きさの違いは各関節 において異なっていた。それは，各関節で生じる生体 の発する力や各関節の角度が相互に影響を受けてい て，違いが生じるためと考えられた。
関節モーメントは関節が回転運動するために必要な 生体から発する力と関係する。身体空間座標と床反力 データから求めることが可能なため, 動作中の筋力を 測定する手段として使用できる. しかし, 関節モーメ ントの值を解釈するうえでいくつかの注意点9,10) が挙 げられる，それは，あらかじめ身体を剛体リンクモデ ルと仮定していること, 各体節の重心位置と質量には 生体物理定数を使用していること, 測定している筋力 は動筋と拮抗筋とで生じる合力であること, 鞀帯など

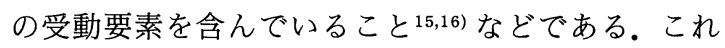
らの点を考慮しても関節モーメントは段昇降動作での 制動力と駆動力とを表しており, 生体が発する力を忠 
実に反映していると考えられた。

\section{結 論}

1）段昇降の際に昇段では先に振り出した脚の股関 節と膝関節の伸展力が駆動として働き, 降段では先に 振り出した脚の股関節と膝関節の伸展力と足関節底屈 力ならびに後から振り出す脚の膝関節伸展力が制動と

して働いていた。

2）生体が発する力のパターンは段の高さの違いに よってもほほ同様であった。

3）生体が発する力は段の高さの違いによってその 大きさを変えていたが，その大きさは各関節によって 異なっていた。

\section{文献}

1) Livingston LA, Stevenson JM, Olney SJ : Stairclimbing kinematics on stairs of differing dimensions. Arch Phys Med Rehabil 1991; 72: 398-402

2) McFadyen BJ, Winter DA : An integrated biomechanical analysis of normal stair ascent and descent. J Biomech 1988; 21 : 733-744

3) Andriacchi TP, Andersson GBJ, Fermier RW, Stern D, Galante JO : A Study of lower-limb Mechanics during stair-climbing. J Bone Joint Surg Am 1980 ; 62A : 749-757

4）宮原洋八, 鈴木堅二, 黒後裕彦, 大町かおり, 今田 元, 岩谷 力: 健常男性成人における段昇降の三次元動作
解析. 総合リハ $1999 ; 27: 555-564$

5）小住兼弘：下腿切断者における段昇降の動作解析. リ 八医学 $1998 ; 35: 170-177$

6）大槻義彦: 物理学入門. 学術図書出版, 東京, 1989

7) Bresler B, Frankel JP: The forces and moments in the leg during level walking. Trans Am Soc Mech Eng $1950 ; 72: 27-36$

8）臨床歩行分析研究会 編：関節モーメントによる歩行 分析. 医歯薬出版, 東京, 1997

9）大橋正洋, 江原義弘, 島田勝英, 前田淳一, 片野由香里, 佐藤房郎：モデル計算による立ち上がり動作時の関節 トルク計測一妥当性および問題点の検討一.リハ医学 $1990 ; 27: 107-113$

10）志波直人, 中村英智, 田川義彦：関節の機能障害一関節 モーメント測定について一. 総合リハ 1996；24：909913

11）植松光俊, 金子公有 : 高齢女性の自由歩行における下 肢関節モーメント. 理学療法学 $1997 ； 24: 369-376$

12) Winter DA: Kinematic and kinetic patterns in human gait: variability and compensating effects. Human Movement Sci $1984 ; 3: 51-76$

13）田中義孝: 変形性股関節症および人工股関節置換術例 の歩行分析. 日整会誌 $1993 ; 67 ： 1001-1013$

14) Perry J : Gait Analysis-Normal and Pathological Function-. SLACK Inc, NJ, 1992

15) Yoon YS, Mansour JM: The passive elastic moment at the hip. J Biomech $1982 ; 15$ : 905-910

16) Mansour JM, Audu ML: The passive elastic moment at the knee and its influence on human gait. J Biomech $1986 ; 19$ : 369-373 